\title{
The Hybrid Entrepreneurs Are Still Working Ambiguously: Will They Have Innovative Behavior
}

\author{
Tyna Yunita \\ Bhayangkara Jakarta Raya University, Faculty of Economics and Business, Jakarta, Indonesia
}

\begin{abstract}
Creativity and innovation are essential components of organizational success in today's economy, a new business advantage. Being innovative is the key so that an organization can continue to survive in a very competitive situation. The work required entrepreneurs to have innovative work behavior. On the other hand, some of them continue to run their business outside of their primary job. This study aims to understand the direct and indirect effects of entrepreneurial culture on innovative behavior in employees who have full-time and part-time jobs. This study identifies entrepreneurial engagement that links the two. The sample of this research was employees of financial institutions with 129 respondents. The research results show that the entrepreneurial culture of hybrid entrepreneurs correlated with entrepreneurial engagement and entrepreneurial engagement has an enormous influence on innovative behavior.
\end{abstract}

Keywords - Entrepreneurial Engagement, Entrepreneurial Culture, Innovative Behavior

\section{Introduction}

In managing individual careers, it is necessary to design the intended career independently.

DOI: $10.18421 /$ SAR42-02

https://doi.org/10.18421/SAR42-02

Corresponding author: Tyna Yunita, Bhayangkara Jakarta Raya University, Faculty of Economics and Business, Jakarta, Indonesia.

Email: tyna.yunita@gmail.com

Received: 23 May 2021.

Revised: 16 June 2021.

Accepted: 22 June 2021.

Published: 27 June 2021.

(C) 2021 Tyna Yunita; published by UIKTEN. This work is licensed under the CC BY-NC 4.0 licence.

The article is published with Open Access at www.sarjournal.com
However, there is still debate about how organizations can help employees do this [1]. On the other hand, several employees have businesses as second jobs. Job transitions can lead to real careers [2]. More specifically, innovation with the support of technology is advantageous in competing in a dynamic business environment. The role of employees has to contribute and implement new ideas because of the organizational level required for the organization, excellence, and long life struggles [3], [4]. Thus, it is crucial to identify factors associated with higher innovative behavior levels among employees [5], [6]. However, there is still little research into the context and mechanisms of innovative behavior in the workplace [7]. R\&D employees have to have innovative behavior in hightech organizations, so they are expected to contribute to their company's innovation [6].

Creativity and innovation are essential components of organizational success in today's economy, a new business advantage. Creativity can produce seeds to develop innovative products, services, solutions, and processes [8], [9].

Innovations that affect the development of a country are a measure of company performance. Innovation gives companies the strength to compete by lowering production costs to increase profitability [10]. Thus, being innovative is the key to an institution or organization to continue to survive in a very competitive time.

Organizations have to create value relationships between knowledge and information, market information and applications, and innovative organizational culture. Organizations enhance customer needs, strengthen innovation behavior, understand competitor actions, internal adjustments, and cross-departmental collaboration to react flexibly to changing markets and achieve innovative values [11]. Additional innovation to increase sustainable products; conversely, radical innovation is needed to develop new products, acquire market share, and increase profits that create corporate innovation behaviors [12]. Continuous innovation organizations that focus on the service industry have to keep pace with changing customer demand patterns for the company's sustainable growth [13] 
Employees' service innovation behavior is the key to the success of service sector innovation. The encouragement of inclusive innovation from the stage holder can increase the service sector's continued expansion [14]. Innovation in maintaining business sustainability is essential [15]. Innovation is developing new ideas and applying them to improve performance [16]. Modern organizations have to create competitive value and make innovation an urgent priority as followers can compete and increase organizational success[15], [17], [18]. The research [19] identified unique contexts and mechanisms where some employees learn, develop and perfect a series of innovative learning skills through entrepreneurial activities applied in the workplace.

This research was conducted to see the hybrid behavior of entrepreneurs in their daily work. Work is required to continue to have innovative work behavior; on the other hand, some of them also continue to run their business outside of their primary job. In uncertain conditions, such as this requires them to remain consistent to remain an employee or enter the world of entrepreneurship as a whole.

\section{Literature Review}

Hybrid entrepreneurship refers to simultaneous participation in wage-employment and entrepreneurship where wage-employees are involved in entrepreneurial activities outside of the primary job role [7], [20]. In this case, part-time entrepreneurs are the founders and owners in a unique learning context that can facilitate the development and transfer of innovative abilities [7].

\subsection{Entrepreneurial Engagement and Innovative Work Behavior (IWB)}

Employees' Innovative Work Behavior (IWB) motivational antecedents contributed to organizational innovation in new processes, services, and products [6]. IWB generates new ideas, solves problems, provides solutions, fights for ideas, and implements ideas [21]. Innovative work behavior (IWB) improves processes, procedures, and processes through stages that implement new ideas in the work role, group, or organization achieved [22].

Engagement captures and explains people's physical, emotional, and cognitive involvement in their work roles [23]. Research engagement is the extent to which individuals appear to be different, explaining how individuals are satisfied with their jobs or value their organizations [24]. People involved in any role cognitively and psychologically make efforts to achieve goals because involvement is influenced by disposition factors [23], [24].

Engagement as a satisfying work experience is likely to lead to positive work results because it has been described [25]. Engagement is positively related to many organizational outcomes [26]. People with positive thoughts will be usually involved in activities they enjoy because they are connected [27]. The positive feelings brought by engagement are likely to produce actual work. Research has established a relationship between positive influences and entrepreneurial work outcomes [28]. Therefore, it is possible that being involved in something that makes someone happy will encourage him to do better or do more business. Also, there is empirical evidence about the relationship between engagement and positive work outcomes. For example, engagement links positively with organizational commitment and negatively to quit [26]. This finding has implications for the results of entrepreneurial work. That is the high engagement needed to produce the results of entrepreneurial work.

There are empirical studies to support the statement that high engagement leads to high performance [26]. High employee engagement is related not to quit [25]. It also deals with extra-role behavior, job performance, and organizational citizenship behavior [26], [27]. Therefore, the hypothesis of this study is as follows:

H1: There is a relationship between Entrepreneurial Engagement of Hybrid Entrepreneurs and Innovative Work Behavior

\subsection{Entrepreneurial Culture and Innovative Behavior}

Innovation in the entrepreneurial process is an intrinsic condition; innovation and entrepreneurship are two interrelated things[29] successful innovative products. Corporate entrepreneur [30] combines and modifies actions and productivity through initiatives, knowledge, training, and commitment following the organizational context, marked by forms of measurement and appreciation. Furthermore, [30] $\mathrm{CE}$, related also to the selection of the right personnel, management philosophy, authorization, and the standards and traditions or values adopted by the organization.

Innovation Behavior is an essential behavior in developing new products and organizational procedures to produce new competitive products and services [11]. Then the research hypothesis is: 
$\mathrm{H}$ 2: There is a relationship between the entrepreneurial culture of hybrid entrepreneurs and innovative work behavior.

\subsection{Entrepreneurial Engagement and Entrepreneurial Culture}

Entrepreneurial Culture [31, pp. 1-2] is "a culture of entrepreneurship which can be understood as norms, values, and codes of conduct that promote social acceptance and approval of entrepreneurial activities resulting in high self-employment rates which persist over time." The studies of entrepreneurial culture are still at the nascent stage, as more studies related to the topic are required [32]. Therefore, the academic gives more attention to Entrepreneurial Culture as a subject of interest in the field, as it impacts employment, business continuity, and growth of the economy. The study results [33] showed a relationship between entrepreneurial culture and innovation output mediated by work engagement. Then the hypothesis can be built as follows:

H3: There is a relationship between the entrepreneurial culture of hybrid entrepreneurs and the entrepreneurial engagement of hybrid entrepreneurs.

Figure 1 shows a research model that describes the relationship between innovative behavior influenced by entrepreneurial engagement and entrepreneurial culture. As well as entrepreneurial engagement variables that mediate the relationship between entrepreneurial culture and innovative behavior.

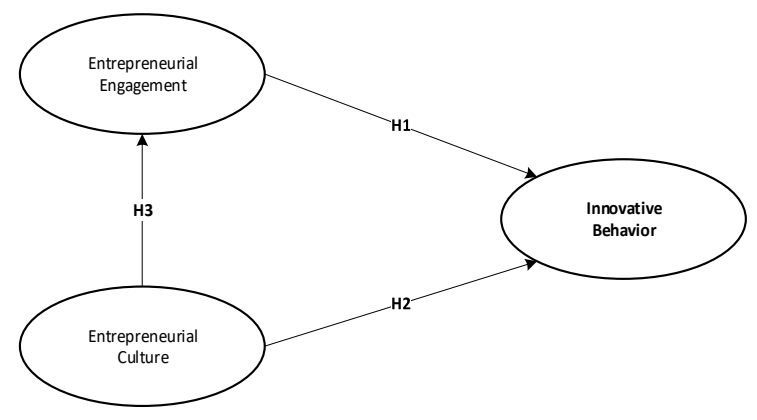

Figure 1. Model Research

\section{Research Methodology}

The research data collection method is to survey hybrid entrepreneurship respondents who work in Jakarta's financial sector. The aim is to ensure that they are a hybrid entrepreneur. The initial question was, "Are you a worker or employee who has a parttime job other than the main job?" If the answer is "Yes", then please complete the questionnaire, and if the answer is "No", you do not need to fill out this questionnaire. This research was conducted by distributing questionnaires to 300 respondents and filling up 129 respondents. The response rate was $43 \%$.

Research questions adopted entrepreneurial culture, innovative behavior [19], and entrepreneurial culture [29] - the analysis technique used SEM (Structural Equation Modeling) with PLS (Partial Least Squares) software.

\section{Validity and Reliability}

The correlation between item scores and construct scores is a convergent validity of the measurement model. The correlation value indicator above 0.70 is considered reliable [34]. The loading indicator value below 0.50 was removed in this study, namely at IB3, IB3, IB5, EC1, EE1, and E2. While the reliability test was measured using composite reliability (CR) and Cronbach alpha. Indicators of $\mathrm{CR}$ and Cronbach alpha values above 0.70 are reliable. The validity and reliability test results are in the following Table 1:

Table 1. Validity \& Reliability

\begin{tabular}{|c|c|c|c|c|c|c|}
\hline \multirow[b]{2}{*}{ 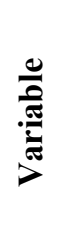 } & \multirow[b]{2}{*}{ 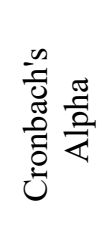 } & \multicolumn{2}{|c|}{ CR } & \multicolumn{2}{|c|}{ AVE } & \multirow[b]{2}{*}{ 包 } \\
\hline & & نே & 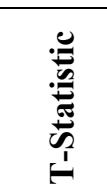 & نٌ & 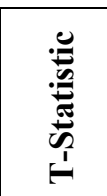 & \\
\hline $\mathrm{EC}$ & 0.845 & 0.908 & 40.496 & 0.664 & 13.946 & supporte \\
\hline $\mathrm{EE}$ & 0.876 & 0.876 & 44.374 & 0.639 & 15.761 & Supporte \\
\hline IB & 0.876 & 0.894 & 62.318 & 0.585 & 16.554 & Supporte \\
\hline
\end{tabular}

From the data above, it appears that the AVE value above 0.50 is declared valid. Cronbach alpha and CR are above 0.70 , so that all constructs have excellent reliability.

\section{Result And Discussion}

Table 2 shows that the age of the respondents is in the age range of 20 to 29 years, as much as $67.44 \%$. Although physical abilities, human capital, and social skills increase with age [35]. As many as $74.42 \%$ are hybrid entrepreneurs with a working period of fewer than five years. Thus, the initial stage in entrepreneurial endeavors becomes an exciting stage and vision for the future [36]. Meanwhile, 59.69\% of hybrid entrepreneurs think that the retail business is an easy starting step.

Table 2 presents the demographics of the respondents in this study. It can be seen that the respondents involved in the study were dominated by respondents who had an age range of 20-29 years, namely $67.44 \%$, the smallest being respondents $>50$ 
years, namely $3.88 \%$. In this study that young people dominate the respondents.

While the work experience of respondents in the range of 0-5 years has the highest number, namely $74.42 \%$, and respondents who have work experience $>10$ years are much smaller, namely $13.63 \%$, which means that participants are still in the early stages of their work careers. The largest category of respondents is the retail group, amounting to $59.69 \%$.

Table 2. Demographics of Respondents

\begin{tabular}{|c|c|c|}
\hline $\begin{array}{c}\text { Demographic } \\
\text { variable }\end{array}$ & Frequency & Percentage \\
\hline Age (years): & & \\
\hline $20-29$ & 87 & $67,44 \%$ \\
\hline $30-39$ & 15 & $11,63 \%$ \\
\hline $40-49$ & 22 & $17,05 \%$ \\
\hline$>50$ & 5 & $3,88 \%$ \\
\hline $\begin{array}{c}\text { Work Tenure as } \\
\text { wage employee } \\
\text { (years): }\end{array}$ & & \\
\hline $0-5$ & 96 & $74,42 \%$ \\
\hline $6-10$ & 18 & $13,95 \%$ \\
\hline $10-15$ & 4 & $3,1 \%$ \\
\hline $16-20$ & 5 & $3,9 \%$ \\
\hline$>20$ & 6 & $6,63 \%$ \\
\hline Hybrid & & \\
Entrepreneurship \\
Role in business:
\end{tabular}

\section{Structural Model}

The next test is done to test the structural model or inner model by looking at the value of $\mathrm{f}^{2}$ with the following criteria: $0.02-0.15$ shows a small effect, $0.15-0.35$ shows a medium effect, $>0.35$ shows an enormous influence.

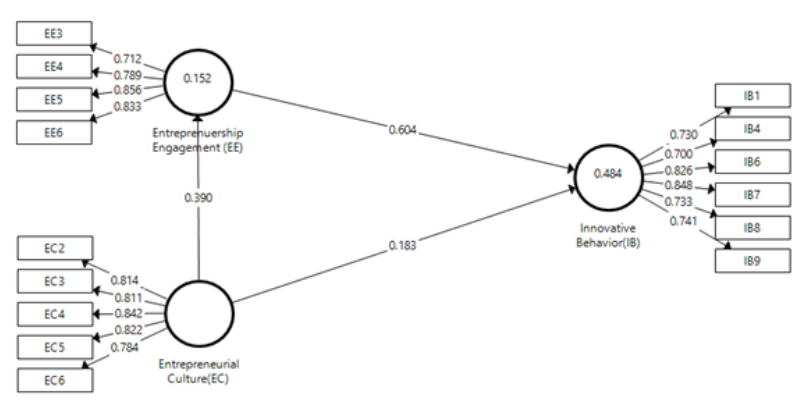

Figure 2. Structural Model

From the structural model analysis, the $\mathrm{f}^{2}$ value is obtained as follows:
Table 3. Relational Variable

\begin{tabular}{|c|c|c|c|c|}
\hline Relation & Loading & $\mathrm{f}^{2}$ & T-Statistic & Finding \\
\hline $\mathrm{EC} \rightarrow \mathrm{EE}$ & 0.390 & 0.180 & 4.560 & Supported \\
\hline $\mathrm{EC} \rightarrow \mathrm{IB}$ & 0.183 & 0.074 & 1.986 & Supported \\
\hline $\mathrm{EE} \rightarrow \mathrm{IB}$ & 0.604 & 0.663 & 7.764 & Supported \\
\hline
\end{tabular}

Table 3 shows the EC $\rightarrow$ IB relationship with a minor influence during $\mathrm{EC} \rightarrow \mathrm{EE}$ and $\mathrm{EE} \rightarrow \mathrm{IB}$ relationship with enormous influence. Then from the mediation of the EE variable, there is an indirect effect, as shown in the following Table:

Table 4. Mediation Variable

\begin{tabular}{|c|c|c|c|}
\hline Relations & Loading & T-Statistic & Finding \\
\hline $\mathrm{EC} \rightarrow \mathrm{EE} \rightarrow \mathrm{I} \mathrm{B}$ & 0.236 & 3.998 & Supported \\
\hline
\end{tabular}

Table 4 shows that EE mediates EC and IB; there is a relationship of 0.236 , so the $\mathrm{H} 1, \mathrm{H} 2$, and $\mathrm{H} 3$ research hypotheses are accepted.

\section{Conclusion}

The data processing results show that the entrepreneurial culture of hybrid entrepreneurs has a medium influence on entrepreneurial engagement and entrepreneurial engagement has an enormous influence on innovative behavior. In other words, hybrid entrepreneurs were supported by entrepreneurial culture in the company where they work; they still have innovative behavior. On the other hand, entrepreneurial culture has little influence on innovative behavior. Alternatively, in other words, innovative behavior in the company where they work is not freely influenced by the existing entrepreneurial culture.

This research cannot be generalized to other industries because this research unit is still narrow or limited to the financial industry in Jakarta. So that further research involve other industries with a broader population and sample.

\section{References}

[1]. Kidd, J. M. (1998). Emotion: An absent presence in career theory. Journal of vocational behavior, 52(3), 275-288. doi: 10.1006/jvbe.1997.1629

[2]. Burton, M. D., Sørensen, J. B., \& Dobrev, S. D. (2016). A careers perspective on entrepreneurship. Entrepreneurship Theory and Practice, 40(2), 237-247. doi: 10.1111/etap.12230

[3]. Amabile, T. M. (1988). A model of creativity and innovation in organizations. Research in organizational behavior, 10(1), 123-167.

[4]. Eide, A. E., Saether, E. A., \& Aspelund, A. (2020). An investigation of leaders' motivation, intellectual leadership, and sustainability strategy in relation to Norwegian manufacturers' performance. Journal of Cleaner Production, 254, 120053. 
[5]. Anderson, N., De Dreu, C. K., \& Nijstad, B. A. (2004). The routinization of innovation research: A constructively critical review of the state-of-thescience. Journal of organizational Behavior, 25(2), 147-173.

[6]. Saether, E. A. (2019). Motivational antecedents to high-tech R\&D employees' innovative work behavior: Self-determined motivation, person-organization fit, organization support of creativity, and pay justice. The Journal of High Technology Management Research, 30(2), 100350.

[7]. Marshall, D. R., Davis, W. D., Dibrell, C., \& Ammeter, A. P. (2019). Learning off the job: Examining part-time entrepreneurs as innovative employees. Journal of Management, 45(8), 30913113. doi: $10.1177 / 0149206318779127$.

[8]. Woodman, R. W., Sawyer, J. E., \& Griffin, R. W. (1993). Toward a theory of organizational creativity. Academy of management review, 18(2), 293-321.

[9]. Kwon, K., \& Kim, T. (2020). An integrative literature review of employee engagement and innovative behavior: Revisiting the JD-R model. Human Resource Management Review, 30(2), 100704. doi: 10.1016/j.hrmr.2019.100704

[10]. Mulkay, B. (2019). How does competition affect innovation behaviour in french firms?. Structural Change and Economic Dynamics, 51, 237-251.

[11]. Chao, C. Y., Lin, Y. S., Cheng, Y. L., \& Liao, S. C. (2011). A research on the relationship among market orientation, absorptive capability, organizational innovation climate and innovative behavior in Taiwans manufacturing industry. African Journal of Business Management, 5(19), 7855-7863. doi: 10.5897/ajbm10.1332.

[12]. Han, S., Cui, W., Chen, J., \& Fu, Y. (2019). Female CEOs and corporate innovation behaviors-Research on the regulating effect of gender culture. Sustainability, 11(3), 682.

doi: 10.3390/su11030682

[13]. Hon, H. Y., \& Lui, S. S. (2016). Employee creativity and innovation in organizations: Review, integration, and future directions for hospitality research. International Journal of Contemporary Hospitality Management, 28(5), 862-885.

[14]. Li, Y., Lin, C., Wu, T., \& Jin, M. (2016). Influences of leader-member exchange on employees' service innovation behaviors. Revista Ibérica de Sistemas $e$ Tecnologias de Informação, (E11), 356.

[15]. Suhana, S., Udin, U., Suharnomo, S., \& Mas' ud, F. (2019). Transformational Leadership and Innovative Behavior: The Mediating Role of Knowledge Sharing in Indonesian Private University. International Journal of Higher Education, 8(6), 15-25.

[16]. Van de Ven, A. H. (1986). Central problems in the management of innovation. Management science, 32(5), 590-607.

[17]. Baer, M. (2012). Putting creativity to work: The implementation of creative ideas in organizations. Academy of Management Journal, 55(5), 1102-1119.
[18]. Pieterse, A. N., Van Knippenberg, D., Schippers, M., \& Stam, D. (2010). Transformational and transactional leadership and innovative behavior: The moderating role of psychological empowerment. Journal of organizational behavior, 31(4), 609-623.

[19]. Marshall, D. R., \& Gigliotti, R. (2020). Bound for entrepreneurship? A career-theoretical perspective on entrepreneurial intentions. International Entrepreneurship and Management Journal, 16(1), 287-303. doi: 10.1007/s11365-018-0523-6

[20]. Folta, T. B., Delmar, F., \& Wennberg, K. (2010). Hybrid entrepreneurship. Management science, 56(2), 253-269.

[21]. De Jong, J., \& Den Hartog, D. (2010). Measuring innovative work behaviour. Creativity and innovation management, 19(1), 23-36.

[22]. Kacmar, K. M., \& Ferris, G. R. (1991). Perceptions of organizational politics scale (POPS): Development and construct validation. Educational and Psychological measurement, 51(1), 193-205.

[23]. Lanaj, K., Chang, C. H., \& Johnson, R. E. (2012). Regulatory focus and work-related outcomes: a review and meta-analysis. Psychological bulletin, 138(5), 998.

[24]. Christian, M. S., Garza, A. S., \& Slaughter, J. E. (2011). Work engagement: A quantitative review and test of its relations with task and contextual performance. Personnel psychology, 64(1), 89-136.

[25]. Schaufeli, W. B., \& Bakker, A. B. (2004). Job demands, job resources, and their relationship with burnout and engagement: A multi-sample study. Journal of Organizational Behavior: The International Journal of Industrial, Occupational and Organizational Psychology and Behavior, 25(3), 293315.

[26]. Saks, A. M. (2006). Antecedents and consequences of employee engagement. Journal of Managerial Psychology, 21(7), 600-619.

[27]. Sonnentag, S. (2003). Recovery, work engagement, and proactive behavior: a new look at the interface between nonwork and work. Journal of applied psychology, 88(3), 518.

[28]. Baron, R. A. (2008). The role of affect in the entrepreneurial process. Academy of management Review, 33(2), 328-340.

[29]. Leal-Rodríguez, A. L., Albort-Morant, G., \& Martelo-Landroguez, S. (2017). Links between entrepreneurial culture, innovation, and performance: The moderating role of family firms. International Entrepreneurship and Management Journal, 13(3), 819-835.

[30]. Peris-Ortiz, M. (2009). An analytical model for human resource management as an enabler of organizational renewal: a framework for corporate entrepreneurship. International Entrepreneurship and Management Journal, 5(4), 461.

[31]. Fritsch, M., \& Wyrwich, M. (2017). The effect of entrepreneurship on economic development-an empirical analysis using regional entrepreneurship culture. Journal of Economic Geography, 17(1), 157189. 
[32]. WU, L. S. (2018). Empirical Study of the Effect of Entrepreneurial Environment on College Students' Entrepreneurial Intention in China. DEStech Transactions on Social Science, Education and Human Science, (aems).

[33]. Ahmetoglu, G., Akhtar, R., Tsivrikos, D., \& Chamorro-Premuzic, T. (2018). The entrepreneurial organization: The effects of organizational culture on innovation output. Consulting Psychology Journal: Practice and Research, 70(4), 318.
[34]. Ghazali, I., \& Latan, H. (2015). Partial Least Squares; Konsep, Tekhnik dan Aplikasi Menggunakan Program Smart PLS 3.0. Semarang: Badan Penerbit Undip.

[35]. Lee, M. O., \& Vouchilas, G. (2016). Preparing to age in place: Attitudes, approaches, and actions. Housing and Society, 43(2), 69-81.

[36]. Carsrud, A., \& Brännback, M. (2011). Entrepreneurial motivations: what do we still need to know?. Journal of Small Business Management, 49(1), 9-26. 